\title{
CORRECTION
}

\section{Correction to: Exosomes in Cardiovascular Medicine}

Iain M. Dykes (1)

Published online: March 8, 2018

(c) The Author(s) 2018. This article is an open access publication

Correction to: Cardiol Ther (2017) 6:225-237

https://doi.org/10.1007/s40119-017-0091-9

This article was originally published under a Creative Commons Attribution-NonCommercial 4.0 International License (CC BY-NC 4.0), but has now been made available under a Creative Commons Attribution 4.0 International License (http://creativecommons.org/licenses/ by/4.0/), which permits unrestricted use, distribution, and reproduction in any medium, provided you give appropriate credit to the original author(s) and the source, provide a link to the Creative Commons license, and indicate if changes were made. The PDF and HTML versions of the paper have been modified accordingly.

\section{OPEN ACCESS}

This article is distributed under the terms of the Creative Commons Attribution 4.0 International License (http://creativecommons.org/ licenses/by/4.0/), which permits unrestricted use, distribution, and reproduction in any medium, provided you give appropriate credit to the original author(s) and the source, provide a link to the Creative Commons license, and indicate if changes were made.

The original article can be found online at https://doi. org/10.1007/s40119-017-0091-9.

I. M. Dykes ( $\square)$

School of Clinical Sciences, University of Bristol, Bristol, UK

e-mail: iain.dykes@bristol.ac.uk 